Tersedia online di: http://ejournal-balitbang.kkp.go.id/index.php/JP
e-mail:jurnalpari@gmail.com
JURNAL PARI
Volume 3 Nomor 1 Juli 2017
p-ISSN: 2502-0730
e-ISSN : 2549-0133

\title{
EVALUASI KINERJA PERPUSTAKAAN: STUDI KASUS DI BALAI BESAR RISET SOSIAL EKONOMI KELAUTAN DAN PERIKANAN
}

\author{
Performance Evaluation of library: Case Study in Research Centre for Marine and Fisheries Socio \\ -Economic (RCMFSE)
}

\section{SITI NURHAYATI}

Balai Besar Riset Sosial Ekonomi Kelautan dan Perikanan

Diterima tanggal : 2 Maret 2017 diterima setelah perbaikan : 19 April 2017 disetujui terbit : 31 Mei 2017

\begin{abstract}
ABSTRAK
Aspek yang sangat penting pada manajemen modern, termasuk didalamnya perpustakaan sebagai sebuah institusi adalah evaluasi kinerja melalui pengukuran indikator-indokator tertentu. Hasil pengukuran indikator kinerja perpustakaan dapat digunakan untuk membandingkan kinerja suatu perpustakaan dari waktu ke waktu. Indikator kinerja perpustakaan adalah suatu alat perencanaan dan evaluasi dengan sasaran mendasar untuk memudahkan kontrol dalam proses manajemen dan menjadi dasar referensi dalam berkomunikasi. Evaluasi kinerja perpustakaan berdasarkan pengukuran kuantitatif terhadap indikator-indikator tertentu yang kemudian dijabarkan secara kualitatif dapat memperlihatkan efektifitas dan efisiensi layanan perpustakaan ke depan. Pengukuran indikator yang dilakukan terhadap layanan perpustakaan pada tahun 2013 ini menghasilkan sebelas data yang dapat digunakan untuk mengukur kinerja perpustakaan tersebut. Sirkulasi tahunan sebesar 155 menunjukkan sirkulasi per kapita sebesar 1,56. Koleksi yang dipakai di ruang baca tercatat sejumlah 720 eksemplar dengan data per kapita 7,27. Total kunjungan ke perpustakaaan sebanyak 720 kali dengan nilai per kapita 7,2. Transasksi referensi tahunan yang terdata sepanjang tahun 2012 adalah sebesar 960, dengan nilai perkapita 9,69. Persentase jumlah pertanyaan yang dapat dijawab sebesar $66 \%$ dengan persentase judul hanya sebesar $21 \%$. Dari Total Permintaan literatur, hanya sebesar $66 \%$ yang dapat dilayani. Nilai Turnover rate yang rendah $(1,3)$ menunjukkan bahwa tingkat penggunaan koleksi di Balai Besar Sosial Ekonomi Kelautan dan Perikanan (BBSEKP) masih sangat rendah.
\end{abstract}

Kata Kunci : Pengukuran Kinerja, Kinerja perpustakaan, Evaluasi Kinerja

\section{ABSTRACT}

An essential aspect on modern management, including library inside in the institution, is the library's performance which could evaluated by measuring it use some certain indicators. The measurement results of the library performance by using some indicators can be used to compare the library performance over time. The measurement results of the library performance indicators can be used to compare the library performance over time. The library performance indicator is a tool for planning and evaluating process in the library services so that the management process could be controlled easily. It's become a basis of reference in the communication activity. Library performance evaluation which conducted base on quantitative measurement toward certain indicators and then elaborated qualitatively can show the effectiveness and efficiency of library services in the future. The measurement of some indicators to library services in 2013 resulted in eleven data that can be used to measure the library performance. The annual circulation of 155 indicates that the circulation per capita is 1.56. The collections usage in reading room as many as 720 exemplars with data per capita is 7,27. Total visits to the library as much as 720 times with value per capita is 7.2. Annual reference transactions recorded throughout 2012 are 960, with per capita value is 9.69. The percentage of questions that can be answered is $66 \%$ with the title percentage of only $21 \%$. Only $66 \%$ of total demand for literature, can be served. A low value of turnover rate indicates that the rate of collections usage in the Center for Socio-Economic Affairs of Marine and Fisheries (BBSEKP) is still very low.

\section{Keywords : Performance; Institution libraries, Information services; Evaluation}

Korespondensi penulis:

Gedung BRSDMKP I lantai 4, JI. Pasir Putih I, Komplek Bina

Samudera, Ancol Timur

Korepondensi: st.nurhayatinatsir@gmail.com 


\section{PENDAHULUAN}

Urgensi pengumpulan data tentang apa yang telah dilakukan oleh perpustakaan menjadi tinggi karena data yang dikumpulkan akan dipakai sebagai dasar pengukuran kinerja untuk menunjukkan buruk atau bagusnya kinerja pengelola sebuah perpustakaan. Tujuan utama pengukuran kinerja adalah untuk memberikan gambaran organisasi dan sebagai bahan evaluasi, apakah perpustakaan tersebut telah berhasil memenuhi misi yang telah di tetapkan. Pengukuran kinerja sebagaimana dijelaskan dalam The IFLA Guideline (1996) adalah sekumpulan data statistik dan data lain yang dapat memberikan gambaran secara gamblang tentang kinerja perpustakaan dan menganalisis data untuk mengevaluasi kinerja. Pengertian evaluasi itu sendiri adalah proses untuk memperhitungkan efektivitas, efisiensi, kegunaan dan relevansi dari suatu layanan atau fasilitas. Kinerja yang dimaksud adalah derajat pencapaian tujuan yang telah ditetapkan, khususnya untuk mengetahui kebutuhan pemustaka. Indikator kinerja yang merupakan pernyataan kuantifikasi digunakan untuk mengevaluasi dan membandingkan kinerja suatu perpustakaan dalam mencapai tujuannya. Indikator ini akan menjadi sangat efisien apabila digunakan untuk mengukur jasa atau layanan perpustakaan yang diterima oleh pemustaka. Indikator tersebut harus mudah digunakan, terpercaya, valid dan dapat dijadikan alat dalam pengambilan keputusan.

Adanya berbagai variasi dalam melakukan pengukuran kinerja lebih banyak yang bersifat kinerja input, seperti jumlah Sumber Daya Manusia, Jumlah koleksi dan lain-lain di bandingkan dengan kinerja keluaran atau hasil. Kalaupun ada, hanya sedikit sekali kinerja keluaran yang diminta dan itu pun tidak dapat dijadikan ukuran untuk melihat kemajuan perpustakaannya. Beberapa data yang diminta antara lain adalah jumlah pengunjung perpustakaan dan jumlah peminjam buku. Padahal masih banyak lagi kinerja perpustakaan khususnya kinerja keluaran yang dapat dilaporkan.

\section{TINJAUAN PUSTAKA}

\section{Pengertian Kinerja}

Kata kinerja memiliki banyak makna. Kamus Umum Bahasa Indonesia mengartikan kinerja sebagai sesuatu yang di capai atau prestasi yang diperlihatkan, kemauan kerja (Pusat Bahasa, 2008). Kinerja berasal dari kata Bahasa Inggris performance. Performance dalam Oxford Advanced Learner's Dictionary yang dapat di akses secara online mengartikannya sebagai the act or process of performing a task, an action. Sedangkan Wikipedia mengartikan kinerja sebagai suatu kondisi yang harus diketahui dan dikonfirmasikan kepada pihak tertentu untuk mengetahui tingkat pencapaian hasil suatu instansi. Dapat pula dihubungkan dengan visi yang diemban suatu organisasi atau perusahaan serta mengetahui dampak positif dan negatif dari suatu kebijakan operasional (Wikipedia, Kinerja). Armstrong dan Baron dalam Wibowo (2007: 2) menjelaskan bahwa kinerja (performance) adalah melakukan pekerjaan dan hasil yang dicapai dari pekerjaan tersebut. Kinerja merupakan hasil pekerjaan yang mempunyai hubungan kuat dengan tujuan strategis organisasi, kepuasan konsumen dan memberikan kontribusi ekonomi. Pendapat lainnya mengenai kinerja yang dikemukakan oleh Hugh J. Arnold dan Daniel C Feldman dalam Nina Lamatenggo dan Hamzah (2012: 118) adalah serangkaian perilaku dan kegiatan secara individual sesuai dengan harapan atau tujuan organisasi. Dari berbagai pendapat oleh para ahli mengenai kinerja diatas dapat disimpulkan bahwa kinerja adalah sebuah bagian yang tidak dapat terpisahkan dari dalam suatu organisasi, yang merupakan prestasi kerja yang dapat diukur, berkaitan dengan kemampuan dan keahlian pribadi yang mempengaruhi tim atau organisasi secara keseluruhan.

\section{Urgensi pengukuran kinerja}

Urgensi dan manfaat dari pengukuran kinerja seperti yang dijelaskan oleh Setyorini, 2007 adalah untuk mengetahui bagian mana saja yang perlu dikembangkan, bagian mana saja yang perlu mendapat alokasi dana, mengetahui prestasi kerja organisasi kita dan posisinya terhadap prestasi kerja organisasi lain yang sejenis, mengetahui posisi kinerja kita dari waktu ke waktu, apakah ada peningkatan ataukah justru terjadi penurunan, mengetahui program, metode, atau personel yang benar-benar menghasilkan dan hemat menggunakan anggaran serta tepat mencapai tujuan

Sedangkan manfaat pengukuran kinerja adalah untuk mengevaluasi, maksudnya adalah untuk menilai seberapa baik sebuah perpustakaan memiliki kinerja. Untuk melakukan evaluasi ini maka perpustakaan harus memiliki data kinerja dan 
standar yang menciptakan suatu kerangka untuk menganalisis data kinerja tersebut. Pengukuran kinerja juga berfungsi untuk pengendalian, sehingga pimpinan perpustakaan memiliki kepastian bahwa staf mereka melakukan pekerjaan dengan benar. Perpustakaan menciptakan sistem pengukuran yang menentukan tindakan tertentu yang harus dilakukan oleh staf. Pimpinan mengevaluasi apakah stafnya telah betul-betul melakukan instruksi yang telah diberikan kepadanya dan membandingkannya dengan standar kinerja. Dari segi penganggaran juga berpengaruh signifikan, karena anggaran adalah salah satu unsur manajemen untuk meningkatkan kinerja. Adanya anggaran yang cukup biasanya akan meningkatkan kinerja perpustakaan. Pengukuran kinerja juga dapat memotivasi, karena target keluaran atau output yang diberikan kepada staf akan mendorong staf tersebut meningkatkan aktifitasnya untuk mencapai target tersebut. Pengukuran kinerja juga dapat bermanfaat sebagai dasar adanya penghargaan, karena perpustakaan juga perlu memberikan penghargaan atas prestasi yang diraih oleh karyawannya sehingga staf perpustakaan lebih merasa bangga dan terikat kepada perpustakaan yang menjadi institusinya (esprit de corp). Selain itu belajar mengevaluasi kinerja yang dicapai oleh perpustakaan akan memberi pembelajaran bagi perpustakaan tersebut agar pengalaman buruk tidak dilakukan lagi sedangkan pengalaman yang baik dapat ditingkatkan lagi. Selanjutnya untuk mengembangkan perpustakaan juga di dapat dilakukan dari hasil pembelajaran sebelumnya, perpustakaan dapat memperbaiki kinerjanya sehingga dapat mengembangkannya menjadi semakin baik (continuous improvement).

Lebih lanjut dijelaskan bahwa indikator kinerja harus (a) tepat (valid) terhadap apa yang ingin diukur, digunakan untuk menjawab pertanyaanpertanyaan tertentu dan hasil yang diperoleh harus mampu menjawab pertanyaan tersebut; (b) Terpercaya (akurat), tidak ambiguitas, tetapi bila yang diukur adalah sikap dan pandangan, maka hasilnya tidak bisa numerik; (c) Reproducible - hal yang sama harus diukur dan cara yang sama pula. Cara yang sama dapat dilakukan untuk mengukur kinerja perpustakaan yang lain pada waktu yang berbeda dan antara perpustakaan yang sejenis; (d) Bermanfaat (informatif) dalam pengambilan keputusan, mampu menginterpretasikan qualitas, kegagalan dan cara untuk meningkatkannyaharus mengacu kepada tujuan perpustakaan; dan (c) Praktis (user friendly), mudah digunakan.

Jacoby (2005) mengatakan bahwa tak jarang suatu organisasi melakukan kesalahan dalam mengukur kinerjanya. Dalam banyak kasus, sering terjadi usaha untuk menutupi pencapaian kinerja yang sebenarnya. Akibatnya akar permasalahan yang dihadapi oleh perpustakaan tidak pernah muncul, sehingga strategi pengembangan perpustakaan dari tahun ke tahun tidak pernah fokus, bahkan jauh dari harapan pemakainya. Setiap penilaian itu akan dapat berdampak pada kebijakan, baik dari sisi anggaran, maupun jenis layanan. Pengukuran menggunakan beberapa indikator akan berdampak pada kebutuhan sumberdaya manusia, dalam hal ini pustakawan dengan kualifikasi tertentu. Pengukuran kinerja ini jelas membantu manajemen untuk melakukan evaluasi guna keperluan perencanaan selanjutnya. Jika setiap perpustakaan melakukan pengukuran kinerjanya secara regular, maka hal ini merupakan peluang bagi pustakawan untuk mengumpulkan angka kredit dari kegiatan pengukuran tersebut. Selain itu diperlukan pula mekanisme untuk menyediakan data yang diperlukan secara rutin, sehingga proses pengumpulan data tidak akan menambah volume pekerjaan harian pustakawan.

\section{METODE PENELITIAN}

Penulisan makalah ini dilakukan dengan metode kualitatif non interaktif yang di padukan dengan studi literatur sekunder yang dianalisis secara deskritif. Metode penelitian kualitatif adalah metode penelitian yang digunakan untuk meneliti kondisi objek yang alamiah dimana penulis merupakan instrumen kunci. Pengambilan sampel untuk penelitian yang menggunakan metode kualitatif dilakukan secara purposive dan snowball. Teknik pengumpulan data dilakukan secara triangulasi kemudian dianalisis secara induktif. (Sugiono, 2013).

\section{HASIL DAN PEMBAHASAN}

Hal yang penting diperhatikan dalam pengukuran kinerja adalah visi, misi dan tujuan serta sasaran perpustakaan. Oleh karena itu suatu sasaran yang baik dan jelas merupakan syarat mutlak. Banyak pihak yang berfikir bahwa dengan adanya pembagian predikat baik, sedang ataupun kurang dapat menjawab semua tuntutan terhadap 
kinerja perpustakaan. Pada makalah ini ada sebelas kinerja hasil atau keluaran yang diperoleh. Ukuran-ukuran di sini dirancang untuk di ukur sekurang-kurangnya sekali dalam satu tahun. Untuk beberapa ukuran diperlukan pengumpulan sampel mingguan, dimana dipilih pada bulanbulan Maret sampai November sehingga dapat mewakili seluruh tahun. Bulan-bulan tersebut direkomendasikan karena pada bulan tersebut merupakan kegiatan paling efektif dan padat di BBRSEKP.

\section{HASIL KINERJA}

\section{Sirkulasi Tahunan (Annual Circulation) $=155$}

Adalah total koleksi yang dipinjam selama satu tahun. Data baru dihitung apabila koleksi dipinjam oleh anggota keluar areal perpustakaan. Perpanjangan peminjaman (renewal) di hitung sebagai peminjaman baru. Dan selama tahun 2012 tercatat 155 transaksi sirkulasi oleh seluruh anggota perpustakaan BBPSEKP.

\section{Sirkulasi Per kapita (Circulation per Capita) $=1.56$}

\section{Jurisdiction Population}

Jumlah sivitas akademika Balai Besar Penelitian Sosial Ekonomi Kelautan dan Perikanan (BBPSE-KP) atau istilah yang digunakan dalam laporan ini adalah Jurisdiction Population adalah jumlah pengguna potensial dalam lingkungan Balai yang wajib dilayani oleh perpustakaan BBPSE-KP sampai dengan desember tahun berjalan. Laporan yang disajikan berupa tabel yang dibagi menjadi dua bentuk, berdasarkan status dan jabatan.

Tabel .1 Pengguna Potensial

\begin{tabular}{|c|c|c|}
\hline No. & Status Kepegawaian & Jumlah \\
\hline 1 & PNS & 56 \\
\hline 2 & Honorer & 1 \\
\hline 3 & Pelaksana & 16 \\
\hline 4 & Tenaga Kontrak & 18 \\
\hline 5 & Cleaning Service & 8 \\
\hline & & 99 \\
\hline No. & Jabatan & Jumlah \\
\hline 1 & Fungsional & 46 \\
\hline 2 & Struktural & 10 \\
\hline 3 & Pelaksana & 16 \\
\hline
\end{tabular}

Dan untuk lebih memperkuat isi laporan, maka di tambahkan pula grafik dari pemustaka di perpustakaan BBRSEKP

Adalah merupakan jumlah item yang di pinjam oleh masing-masing anggota populasi yang bertujuan mengukur jumlah item yang di sirkulasikan oleh perpustakaan terhadap populasi yang wajib dilayani oleh perpustakaan BBPSEKP. Sasaran indikator ini adalah menilai banyaknya penggunaan koleksi diperpustakaan.

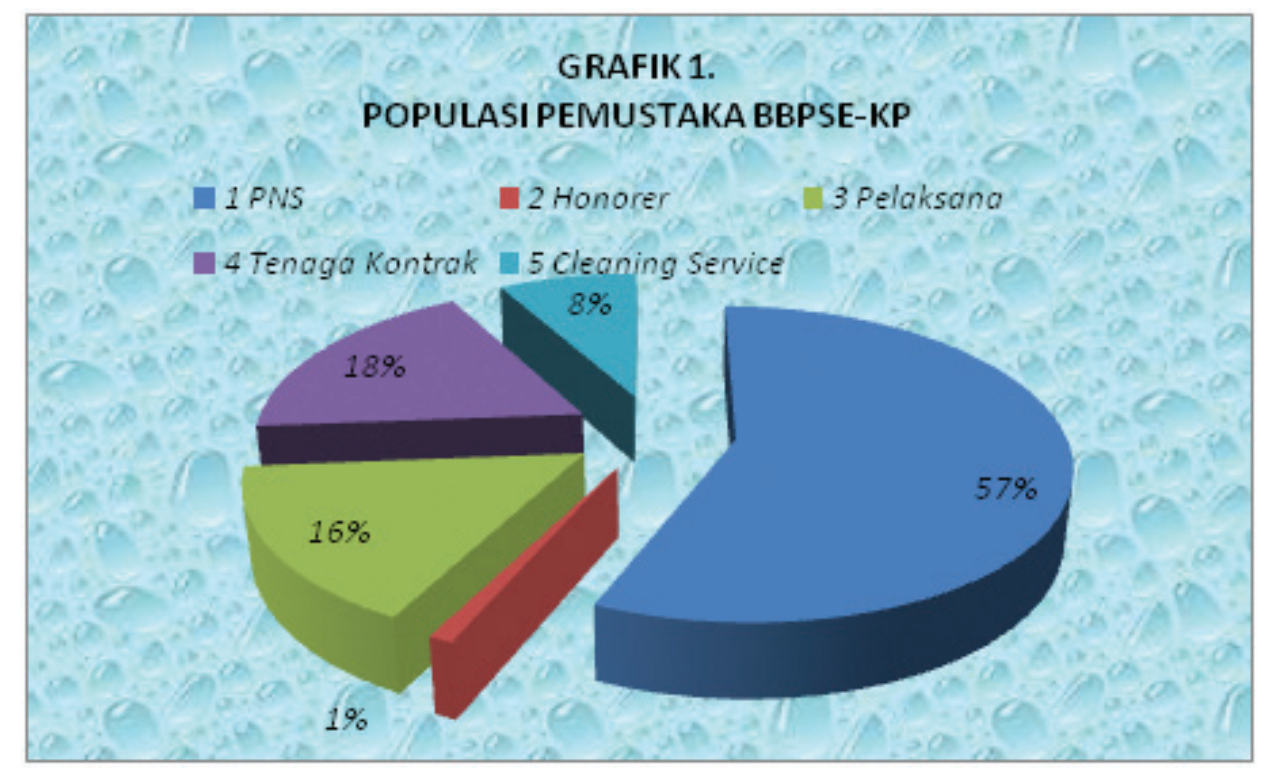

Gambar 1. Populasi Pemustaka di Perpusatkaan BBRSEKP tahun 2012 berdasarkan Status Kepegawaian 


$$
\begin{gathered}
C p C=A C \\
J P \\
C p C=155 \\
99 \\
C p C=1.56
\end{gathered}
$$

\section{Dimana:}

- Annual Circulation (AC) adalah jumlah buku yang dipinjamkan kepada pengguna selama satu tahun

- Jurisdiction Population(JP) adalah jumlah populasi yang wajib dilayani oleh perpustakaan

- Circulation perCapita (CPC) adalah jumlah rata-rata peredaran buku (dalam bentuk Dipinjam ke luar perpustakaan) kepada pengguna perpustakaan.

Artinya setiap satu orang sivitas akademika BBPSE-KP meminjam rata-rata 2 eks selama tahun 2012

\section{Koleksi yang di pakai diruang baca pertahun (Annual in-library Material Use) $=720$}

Annual In-Library Material Use di sebut juga In Library Material Use atau iLMU, yaitu jumlah item koleksi yang digunakan (di perpustakaan) oleh pengunjung selama satu tahun, sehingga dapat di ketahui seberapa besar manfaat dari investasi pengadaan koleksi yang sudah di lakukan oleh perpustakaan BBPSE-KP. Angka ini didapat dari rata-rata jumlah buku yang di shelving oleh perpustakaan perhari 3 eks.(buku dan bahan pustaka lain) di kali 20 hari kerja selama tahun 2012.

\section{Koleksi yang di pakai di ruang baca per kapita ( In-Library Material Use percapita) $=7.27$}

Mengukur estimasi jumlah material yang digunakan oleh pemakai di dalam perpustakaan (tidak dipinjam/ di bawa keluar), jadi yang di ukur disini adalah seluruh jenis bahan pustaka yang dikoleksi oleh perpustakaan BBPSE-KP yang di ambil dari rak koleksi baik yang di bantu oleh staf maupun oleh pemakai sendiri untuk digunakan didalam ruangan perpustakaan.

$$
\begin{gathered}
\mathrm{ILMUpC}=\mathrm{iLMU} \\
\mathrm{JP} \\
\mathrm{ILMUpC}=720 \\
99 \\
\mathrm{ILMUpC}=7.27
\end{gathered}
$$

\section{Dimana:}

- In-Library Material Use (iLMU) adalah jumlah koleksi perpustakaan yang digunakan ditempat (tidak dipinjam keluar perpustakaan) oleh pemakai perpustakaan selama satu tahun

- Jurisdiction Population(JP) adalah jumlah populasi yang wajib dilayani oleh perpustakaan

In-library Matreial Us perCapita (iLMUpC) adalah jumlah rata-rata koleksi yang dipakai ditempat atau Perpustakaan oleh setiap pemakai perpustakaan

Artinya rata-rata setiap sivitas akademika BBPSE-KP menggunakan 7 eks, buku yang hanya di baca di tempat, tidak di pinjam (dibawa pulang)

\section{Kunjungan ke Perpustakaan per tahun (Annual Number of Library Visits) $=\mathbf{7 2 0}$}

Salah satu ukuran yang sering digunakan untuk mengetahui kinerja perpustakaan BBPSE$\mathrm{KP}$ adalah jumlah pemakai yang datang atau berkunjung ke perpustakaan selama periode waktu tertentu, dan untuk laporan kali ini kami memasukan datadari Januari 2012 s.d Desember 2012 yang perharinya rata-rata 3 orang yang mengunjungi perpustakaan, sehingga jumlah dalam satu tahun sebanyak 720 kunjungan, namun yang mencatatkan kedatangannya pada buku tamu hanya 85 orang.

\section{Kunjungan ke Perpustakaan per kapita $=$ 7.2}

Idealisme dari ukuran ini adalah setiap individu dari sivitas akademika (pemustaka di BBRSEKP) mengunjungi perpustakaan dalam jumlah yang sama setiap tahun, misalnya setiap orang mengunjungi perpustakaan sebanyak $X$ kali. Angka frekuensi kunjungan pertahun di dapat dari :

- Annual Number of Library Visit (ALV)

$$
\begin{array}{r}
\mathrm{LVpT}=\mathrm{ALV} \\
\mathrm{JP} \\
\mathrm{LVpT}=720 \\
99 \\
\mathrm{LVpT}=7.2
\end{array}
$$
adalah jumlah total kunjungan pemakai ke perpustakaan selama satu tahun.

- Jurisdiction Population (JP) adalah jumlah populasi pemustaka yang wajib dilayani oleh perpustakaan BBPSE-KP. Maksudnya jumlah pemustaka di lingkup BBRSEKP saja, bukan jumlah perguruan tinggi yang potensi untuk dilayani 
- Library Visit perCapita (LVpT) adalah ratarata kunjungan setiap orang (pemakai) ke perpustakaan BBPSE-KP

Sehingga dapat di artikan bahwa selama tahun 2012 setiap sivitas akademika BBPSE-KP mengunjungi perpustakaan sebanyak 7 kali.

\section{Transaksi Referensi Tahunan (Annual Reference transaction) $=960$}

Ukuran ini disebut juga Number of Reference Transaction, berhubungan dengan jumlah layanan referensi kepada pemakai dalam hal ini seluruh pegawai di lingkup BBPSE-KP yang melibatkan intervensi staf perpustakaan, artinya penggunaan bahan referensi yang dilakukan sendiri oleh pemakai tidak di hitung sebagai reference transaction. Namun semua permintaan informasi baik yang disampaikan secara langsung maupun melalui surat, faximile, email, telepon oleh pemakai yang memerlukan koleksi perpustakaan untuk keperluan informasi, dihitung sebagai reference transaction.

Pertanyaan ini termasuk pertanyaan bagaimana cara menggunakan katalog; bantuan penelusuran informasi dan literatur; bimbingan kepada pembaca; pertanyaan yang bersifat referensi terhadap sumber-sumber informasi, bantuan untuk mendapatkan informasi fakta dan sebagainya. Pertanyaan-pertanyaan yang sangat sederhana seperti "apakah perpustakaan buka sampai malam?' atau " dimana letak lemari katalog?" tidak di kategorikan pertanyaan referens yang dapat di hitung.

Jumlah pertanyaan perhari yang di terima pustakawan dan staf perpustakaan rata-rata 4 pertanyaan dari seluruh pengunjung, berdasarkan ini, maka dapat di simpulkan bahwa sepanjang tahun 2012 ada 960 pertanyaan yang diterima berkenaan dengan perpustakaan dan koleksinya, yaitu :

$$
\begin{aligned}
& A R T=Q . D . M \\
& A R T=4.20 .12 \\
& A R T=960
\end{aligned}
$$

\section{Dimana :}

- Annual Number of Reference Transaction (ART) adalah jumlah total transaksi pertanyaan referensi selama satu tahun

- Question (Q) adalah jumlah pertanyaan perhari yang di terima pustakawan
- Day (D) adalah jumlah hari kerja pustakawan

- Month (M) adalah jumlah bulan efektif untuk lama bekerja pustakawan.

\section{Transaksi Referensi Perkapita (Reference Transaction Per Capita)}

Untuk tujuan pengukuran ini, transaksi referensi atau Reference Transaction di definisikan sebagai semua permintaan informasi, baik yang disamapikan secara lansgung mapun surat oleh pemustaka yang memerlukaninformasi. Ukuran ini [un hanya digunakan untuk layanan yang melibatkan intervensi staf perpustakaan, artinya penggunaan bahan referensi yang dilakukan langsung oleh pemustaka tidak dapat di hitung sebagai reference transaction.

Angka Reference Transaction Per Capita $(\mathrm{RTpC})$ di dapat dari :

$$
\begin{aligned}
& \mathrm{RTpC}=\mathrm{ART} \\
& \mathrm{RTpC}=960 \\
& \mathrm{RTpC}=9.69
\end{aligned}
$$

\section{Dimana :}

Annual Number of Reference Transaction (ART) adalah jumlah transaksi pelayanan referensi yang diberikan kepada pemakai perpustakaan selama satu tahun.

- Jurisdiction Population (JP) adalah jumlah populasi pemustaka yang wajib dilayani oleh perpustakaan BBPSE-KP, sudah ada penjelasan, terkait jurisdiction population

- RTpC : Reference Transaction perCapita (RTpC )adalah rata-rata pelayanan referensi yang diberikan kepada setiap pemakai perpustakaan selama satu tahun.

Artinya setiap sivitas akademika BBPSE-KP sepanjang tahun 2012 mengajukan 9-10 pertanyaan kepada pustakawan dan staf perpustakaan BBPSE$\mathrm{KP}$

\section{Reference Fill Rate}

Adalah persentase jumlah pertanyaan yang dapat dijawab terhadap total pertanyaan referens yang di terima. Persepsi terhadap pertanyaan yang dapat di jawab atau tidak diserahkan kepada petugas referens. Di Perpustakaan BBPSE-KP sendiri saat ini belum ada petugas khusus untuk layanan referens, akan tetapi tugas ini di serahkan 
juga kepada staf yang sedang bertugas di bagian layanan.

Unsur data yang digunakan dalam penghitungan Reference Fill Rate adalah jumlah transaksi referens (Number of Reference Transaction) dan jumlah transaksi referensi yang dapat di jawab atau di selesaikan (Number of Reference Transaction complete). Di Perpustakaan BBRSEKP mempunyai data aktual mengenai pertanyaan yang id terrima dan pertanyaan yang di jawab, maka reference fill rate nya dapat di hitung dari data aktual ini.

$$
\begin{aligned}
& \begin{array}{l}
\mathrm{RFR}=(\mathrm{RTC}) \\
\mathrm{TRT}
\end{array} \times 100 \% \\
& \begin{array}{c}
\mathrm{RFR}=(480) \\
960
\end{array} \times 100 \% \\
& \mathrm{RFR}=66 \%
\end{aligned}
$$

- Number of Reference Transaction Complete (RTC) adalah jumlah transaksi pelayanan referensi yang dapat dilayani (dapat di jawab)

- Total Number of Reference Transaction (TRT) adalah total transaksi pelayanan referensi selama satu tahun.

- Reference Fill Rate (RFR) adalah presentase jumlah transaksi layanan referensi yang dapat dijawab terhadap total transaksi layanan referensi

Artinya dari total pertanyaan yang di ajukan sepanjang tahun 2012 (960), hanya 66\% nya saja atau 480 pertanyaan yang dapat di jawab , biasanya disarankan menggunakan judul lain yang subjeknya sama.

Contoh pertanyaan referens:

Yang dapat di jawab :

User : "Mba' ada buku yang tentang budidaya ikan air tawar ndak?"

Pustakawan : "Ada, kami punya 5 judul, yang sedang di pinjam 3 judul, ada di kelas 639 , lemari 4 rak kedua"

Yang tidak dapat di jawab:

User : "Mba, ada novel Twilight ndak?"

Pustakawan : "Twilight kita belum punya, adanya novel kembara bahari, atau kalo' mau liat ke rak langsung, coba aja ke lemari 5, rak ke satu dan kedua"

\section{Tittle Fill Rate $=$}

Mengukur persentase judul tertentu yang diinginkan oleh pemakai yang tersedia di perpustakaan terhadap total permintaan pemakai tersebut, termasuk permintaan melalui telepon, fax dan email. Data yang diperlukan untuk mengukur kinerja ini adalah jumlah judul yang dicari dan jumlah judul yang ditemukan. Data ini biasanaya di dapat dari survey yang dilakukan terhadap pemakai, atau dapat pula menggunakan catatan kegiatan harian dari pustakawan berupa formulir. Dengan menggunakan form isian, baik yang di isi oleh pemustaka maupun pusatakawan, dapat menjadi dasar perhitngan Tittle Fill Rate ini. Kemudian rumus yang di dapat adalah sebagai berikut :

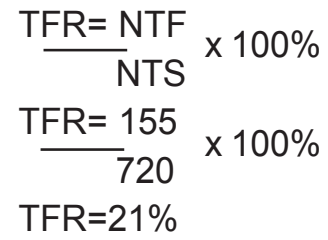

- Number Title Found (NTF) adalah jumlah penelusuran melalui judul koleksi (buku dan bahan pustaka lainnya) yang dapat ditemukan, berdasarkan judul buku yg dipinjam pemustaka.

- Number Title Sought (NTS) adalah jumlah seluruh penelusuran melalui judul, berdasarkan jumlah kunjungan pertahun, dengan asumsi satu pertanyaan setiap pengunjung.

- Title Fill rate (TFR) adalah persentase jumlah penelusuran melalui judul koleksi yang ditemukan terhadap total penelusuran.

Artinya dari total 720 pertanyaan berdasarkan judul, hanya ada 155 pertanyaan atau $21 \%$ yang dapat di jawab dengan 'ada' atau 'ada tetapi sedang di pinjam'

\section{Subject and Author Fill Rate}

Dalam hal ini yang di ukur adalah permintaan literature menggunakan subjek dan pengarang. Data yang diperlukan untuk mendapatkan angka ini adalah jumlah permintaan literatur berdasarkan subjek dan pengarang dan jumlah yang ditemukan. Rumus yang digunakan adalah sebagai berikut:

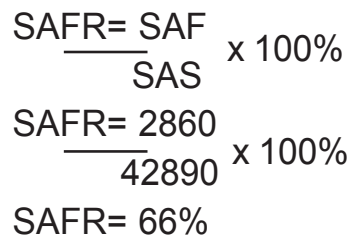

\section{Dimana:}

- Number of Subject and Author Found (SAF) adalah jumlah penelusuran melalui topic dan 
pengarang koleksi (buku dan bahan pustaka lainnya) yang dapat ditemukan

- Number of Subject and Author Sought (SAS) adalah jumlah seluruh penelusuran yang dilakukan melalui topic dan pengarang

- Subject and Author Fill Rate (SAFR) adalah persentase penelusuran melalui topik dan pengarang yang di temukan terhadap jumlah seluruh penelusuran yang dilakukan melalui topik dan pengarang

Artinya dari 4.290 pertanyaan berdasarkan subjek 7 penulis atau pengarang, hanya 2.860 saja yang dapat di jawab atau 66\%-nya.

\section{Turnover Rate}

Mengukur frekuensi rata-rata koleksi yang digunakan baik keluar perpustakaan maupun di dalam perpustakaan. Pengukuran ini dilakukan untuk mengetahui berapa sebenarnya rata-rata sebuah koleksi dipakai baik dipinjam keluar perpustakaan maupun digunakan didalam perpustakaan. Data yang diperlukan untuk mengukur Turnover Rate adalah jumlah total buku yang dipinjam atau digunakan selama satu tahun dan jumlah koleksi dalam satuan eksemplar.

$$
\begin{aligned}
& \frac{\mathrm{TR}=\mathrm{AC}}{\mathrm{iLMU}}: \mathrm{HD} \\
& \text { TR=155 : } 2341 \\
& 480 \\
& \mathrm{TR}=1.3
\end{aligned}
$$

- Annual Circulation (AC) adalah jumlah koleksi perpustakaan yang dipinjamkan

- kepada pemakai selama satu tahun

- In-Library Materaial Use (IImu) adalah jumlah koleksi perpustakaan yang digunakan ditempat (tidak dipinjam keluar perpustakaan) oleh pemakai perpustakaan selama setahun.

- Holdings (HD) adalah jumlah eksemplar koleksi perpustakaan

- Turnover rate (TR) adalah rata-rata frekuensi koleksi yang dipinjam oleh pemakai selama satu tahun.

Semakin besar angka turnover rate ini, semakin tinggi prestasi sebuah perpustakaan. Untuk meningkatkan angka ini perpustakaan selain harus berusaha untuk mempromosikan koleksi perpustakaannya juga harus menyeleksi buku atau bahan pustaka lain yang akan di koleksi.

\section{KESIMPULAN DAN SARAN}

Melihat dari paparan kinerja yang diambil dari pedoman pengukuran kinerja perpustakaan terbitan FPPTI, isi dari laporan tersebut sudah cukup baik dan dapat dipahami oleh pemustaka dan stakeholder, dalam hal ini pihak pimpinan di BBRSEKP, baik dari segi undersandability maupun dari readability. Laporan Kinerja hasil tersebut akan menjadi sebuah dokumen yang sangat efektif untuk menginformasikan sekaligus mempromosikan perpustakaan BBRSEKP. Dengan total populasi sejumlah 99 dapat di ketahuinya hasil Circulation per capita yang sebesar 1,56 dengan jumlah keseluruhan peminjaman seluruh koleksi selama satu tahun sebanyak 155 , dibagi dengan jumlah keseluruhan dokumen koleksi yang dimiliki. Selain itu indikator ini juga dapat digunakan untuk menilai kesesuaian koleksi dengan kebutuhan populasi yang dilayani. In Library Material Use per Capita adalah jumlah dokumen yang digunakan diperpustakaan selama satu tahun dibagi jumlah populasi yang dilayani, didapat sebesar 7,27 , kunjungan ke perpustakaan per kapita 7,2 adalah jumlah keseluruhan kunjungan ke perpustakaan selama satu tahun penuh di bagi dengan jumlah keseluruhan orang dalam populasi yang di layani. Maksud dari kunjungan adalah tindakan memasuki perpustakaan dengan izin untuk menggunakan salah satu dari layanan yang disediakan. Reference Transaction per Capita sebesar 9,69 diartikan bahwa setiap pemustaka mengajukan 9-10 pertanyaan pada tahun 2012, Reference Fill Rate di Perpustakaan BBRSEKP sebesar $66 \%$ dengan nilai tittle fill rate yang hanya $21 \%$, ini menjelaskan kurangnya koleksi yang update dan dibutuhkan oleh pemustaka di BBRSEKP. Subject and Author Fill Rate juga menjelaskan hal yang sama, hanya sebesar $66 \%$ saja dari pertanyaan yang masuk dapat di jawab oleh pustakawan - Sedangkan Turnover Rate yang merupakan frekuensi rata-rata koleksi yang digunakan hanya sebesar 1.3.

\section{DAFTAR PUSTAKA}

Anonim. 2014. Penelitian Literatur. http:// dapurilmiah.blogspot.co.id/2014/06/ penelitian-literatur.html (diakses pada tanggal 14 September 2017) 
Anonim. $2017 \quad$ http://www. oxfordlearnersdictionaries.com/definition/ english/performance?q =performance (diakses pada tanggal 14 September 2017)

Anonim. 2017. https://id.wikipedia.org/wiki/ Kinerja (diakses pada tanggal 14 September 2017)

Arikunto, Suharsimi. 2015. Prosedur Penelitian Suatu Pendekatan Praktik. Jakarta: PT Rineka Cipta

Burhan Bungin : "Metode Penelitian Kualitatif: Aktualisasi Metodologis kea rah ragam varian kontemporer, Rajawali pers Ed. 1 cet. 9, Jakarta 2012.

Courtis,John K :" Readibility of Annual Reports : Western vs Asian Evidence. Accounting, Auditing \& Accountability Journal. Vol.8 No. 2 pp. 4-17

Erwin:"Filsafat Sains dan Agama" tersedia pada http://teraserwin.blogspot.co.id/2014/12/ filsafat-sains-dan-agama.html (diakses pada 15 September 2017)

IFLA. Measuring quality: international guidelines for performance measurement in academic libraries, Munich, Saur, 1996.

Institut Pertanian Bogor, Perpustakaan Indonesia menghadapi Era Open Access, Penerbit IPB, Bogor 2013.

Irawan, 2006. Penelitian Kualitatif Dalam Penerapan, Terj. Pekanbaru: Depdiknas Pusat Bahasa, Balai Bahasa Pekanbaru, 2000

Jacoby, David. Measuring sourcing performance: What's the mystery? Purchasing; Jun 2, 2005; 134, 10; ABI/INFORM Global pg. 60
Pawit M. Yusup :" Perspektif Manajemen Pengetahuan Informasi, Komunikasi, Pendidikan dan Perpustakaan, Rajawali Pers ed. 1 Jakarta 2012.

Pusat Dokumentasi dan Informasi IImiah.2007. Indikator Kinerja Perpustakaan berdasarkan standar Inyternasional. LIPI; Jakarta 2007.

Putu Laxman Pendit : Perpustakaan Digital : Kesinabungan dan dinamika; Cita Karyakarsa Mandiri, Jakarta 2009.

Rahayuningsih, F. 2007, Pengelolaan Perpustakaan, Yogyakarta: Graha IImu.

Setyorini, Dyah : Laporan Tahunan VS Ringkasan Laporan Tahunan. Jurnal Ekonomi dan Pendidikan, Volume 4 Nomor 1, 2007.

Sugiyono. (2013). Metode Penelitian Kuantitatif, Kualitatif, dan R\&D.Cetakan ke-19. Bandung: Alfabeta.

Surtiawan, Dwi. Kepuasan Pemakai dan Peningkatan Kualitas Berbasis Pemakai: Pendekatan Manajemen Pemasaran sebagai Paradigma Baru Perpustakaan. 2006.

Sutarno,N.S. 2006. Perpustakaan dan Masyarakat Ed. Rev. Jakarta : Sagung Seto

Wibowo. 2007. Manajemen Kinerja. Jakarta: Raja Grafindo Persada.

Widodo, Joko. 2006. Membangun Birokrasi Berbasis Kinerja. Jakarta: Bayumedai Publishing. 